\title{
CSR in Vietnam: What factors would promote CSR in Vietnam?
}

\author{
Student name: Nguyen Thai Son \\ Student ID. No: VNSIM2017015 \\ MSM MBA VN Intake 21 \\ Subject: Corporate Responsibilities and Ethics \\ Instructor: Prof. Nika Salvetti
}

$-00$

This paper was submitted in partial fulfillment of the requirements for the Master in Business Administration (MBA) degree at the Maastricht School of Management (MSM) Intake 21 - COPORATE SOCIAL RESPONSIBILITY \& BUSINESS ETHICS.

Ho Chi Minh City, Viet Nam, 11/2019

[9 pages -2192 Words Count] 


\section{TABLE OF CONTENTS}

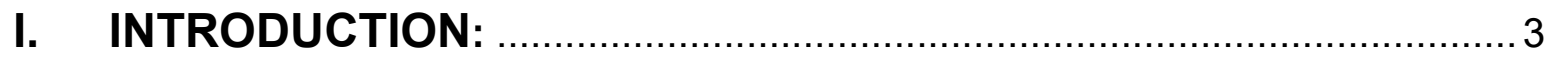

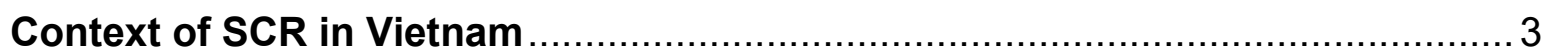

II. WHICH FACTORS WOULD PROMOTE CSR IN VIETNAM: $\ldots \ldots \ldots \ldots . . . . .3$

1. Socio-cultural and politico-economic context of Vietnam.............3

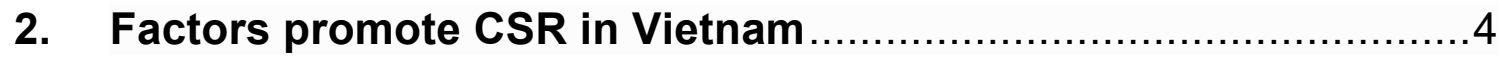

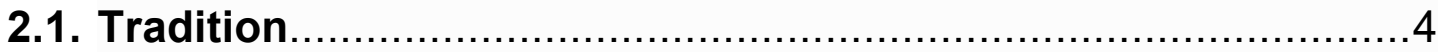

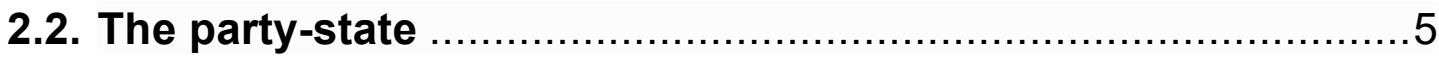

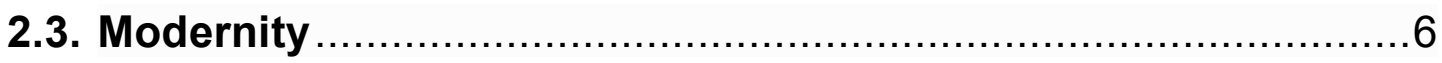

III. PROBLEMS AND MANAGERIAL RECOMMENDATIONS ............7

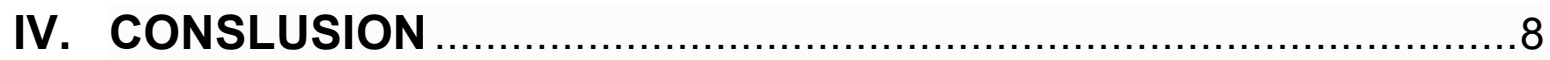

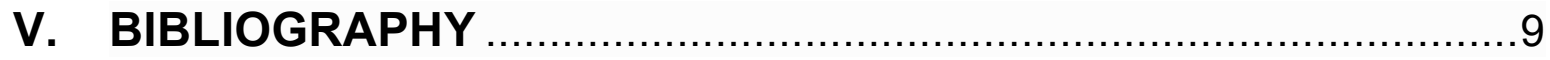




\section{INTRODUCTION}

After the last two decades from 2000, Vietnam had a dynamic growth in GDP with annual GDP growth not less than 5\% and hit a peak at 7.1\% in 2018 (General Statistics Office of Vietnam). Come along with this economic growth Vietnam, enterprises have faced with a lot of challenges especially regarding their impact on society and environment.

Besides, Vietnam witnessed many business scandals, for example, avoiding and evading taxes of Coca-Cola in 2012 (lyer, 2013), environmental pollution of Formosa case in 2016 (Ortmann, 2017), disproportionate payment of Nike case in 1997 (Greenhouse, 1997), low-quality medicine importing in the case of VN Pharma in 2017 (Tuoi Tre News, 2017). Thus, CSR activities in Vietnam have been critized because of implementing fundamental principles of CSR in a distorted way (Anner, 2012; Bilowol and Doan, 2015). Therefore, all cases have raised significant awareness of consumers about how enterprises doing their businesses and their effects on society, environment and all of these are creating dark spots on CSR in Vietnam.

As we can see clearly that the role of CSR in Vietnam need to be enhanced and encouraged properly by the stakeholders in relation of each others to catch up with MNCs, western governments, and international organizations in political, legal and economic levels. Since they introduced this concept of CSR to Vietnam in 2002 (Hamm,2012). However, when applying CSR practices in Vietnam, MNCs need to adapt and modify to particular situations of Vietnam. For instance, they seem to recognize and finally find a way to respect and implement CSR projects that support the Buddhist or socialist beliefs of their Vietnamese employees, partners and authorities (Bilowol and Doan, 2015).

In this essay, we will discuss about what factors would promote CSR in the context of Vietnam.

\section{WHICH FACTORS WOULD PROMOTE CSR IN VIETNAM}

\section{Socio-cultural and politico-economic context of Vietnam}

Vietnam is a multi-ethnic cultural nation, suffered from Chinese feudal dysnasties then one hundred year in French domination (1858-1954), and 30 years under colonization of American. However, Vietnamese still holds the unique national identity despite of huge foreign influence due to patriotism and nationalism to hold country as a unity with diversity culture after a long period of national fragmentation (Edwards \& Phan, 2008).

The government still played an important role in assigning members to both public administration and the state sector for managerial positions (Edwards \& Phan, 2008). Since 2000 , the party-state put effort to enhance private companies by establishing 
the first stock market and foreign trade agreements (Rowley \& Truong, 2009). However, all economy is still mainly affected by socialist direction of state reflected for example, by maintanance of state-owned enterprises (SOEs) as the key position in economy (Vuong, 2014).

\section{Factors promote CSR in Vietnam}

The idea is based on a CSR conceptual model built for the model of Vietnamese management derived from the study of Eward and Phan (2014). This CSR concept show that three contextual key factors which are tradition, modernity and the party-state drive the CSR activities in Vietnam (see Figure 1)

Figure 1 Conceptual framework of CSR

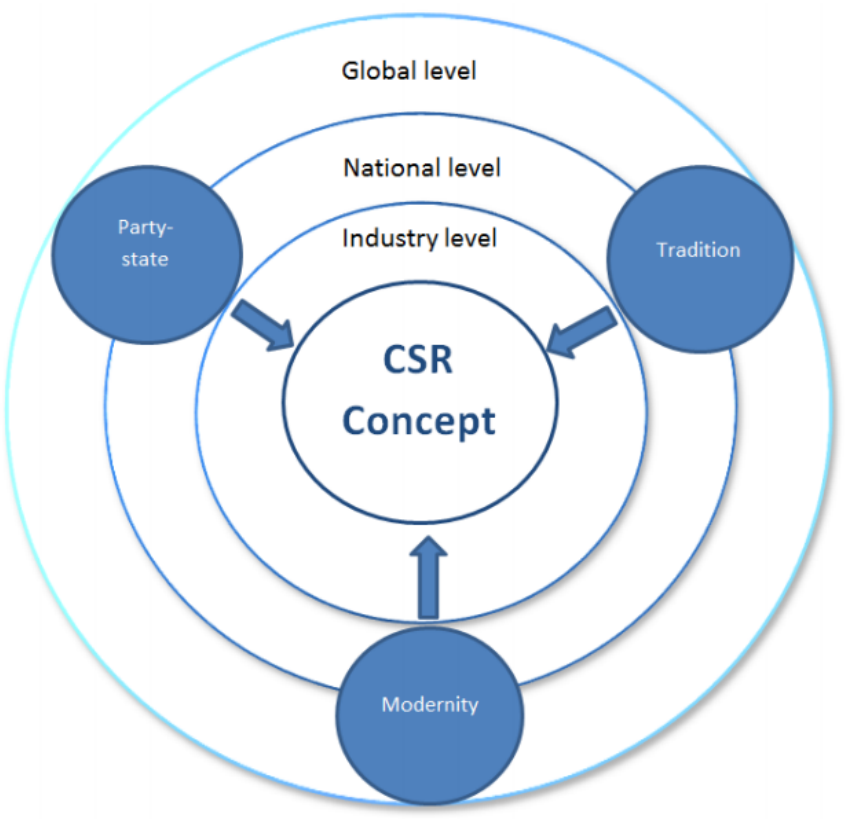

\subsection{Tradition}

Through 4000 years of building and protection country, Vietnam established the strong and distinctive tradition which is the main spirit of Vietnamese. Based on a study of Nguyen. et al (2018), tradition factors comprise main elements such as Confucian values, religious beliefs, familialism and nationalism. Besides, many CSR researchers have argued that CSR is bonded to cultural values and norms and in Asia, even the CSR concept derived from specific cultural traditions (Visser et al., 2008).

\section{Confucian}

Many perspectives in our Vietnamese mindset drived from Confucian ideology such as "tam cương" (three relationship between king-people, parents-children, wife-husband), "ngũ thường - nhân nghĩa lễ trí tín" (humanity, reasonable respectful, knowledgeable, 
reliable). These ideas can affect to behaviors of Vietnamese to others and also to CSR practices implementation.

\section{Religious beliefs}

Vietnamese with $26.4 \%$ are religious with $14.91 \%$ Buddhism followed by $7.35 \%$ Roman Catholicism (International Religious Freedom Report - Vietnam 2018). Hence, Buddhism plays an important role on the way of thinking and acting or ethical bebaviors toward others in Vietnam society. For example, one of the most important phylosophies of Buddhism is casual law which tells that "everything that happens to you is the result of your own actions"

In business practices of domestic enterprises in term of CSR literature, they did charity for supporting the poor, donated religious activities, celebrated for children of employees in Mid Autumn night, give employees bonus $13^{\text {th }}$ month wage in Lunar New Year (Tran \& Jeppesen, 2016).

\section{Nationalism and Familialism}

In Vietnamese tradition, cultural values and norms are also shaped by familialism and nationalism, and it is well known that Vietnamese are collectivist in general and socialized to fight for the interests of the nation (Rowley and Truong, 2009).

The beliefs in Buddhism, nationalism and familsm of Vietnamese may represent for the philanthropic responsibilities in conception of CSR in Vietnam.

\subsection{The party-state}

During the economic liberalization period recently in Vietnam, there is evidence showing that the party-state still tries to maintain socialist values by variety of political tools that potentially affects the nature of CSR (Tran, 2011). Overall, based on a study of Nguyen. et al (2018), political governance forces may comprise three main elements which are official political ideology, state ownership, and legislation and standards.

\section{Political ideology}

Firstly, the government attempts to govern business practices in line with its official ideology. In Vietnam, socialist perceptions are officially acknowledgeable frameworks that ties society (Abuza, 2001) and CSR might be a way that government propaganda their ideologies. For example, from 2010, Vietnam Chamber of Commerce and Industry (VCCI) established the Vietnam Business Council for Sustainable Development (VBCSD) in order to promote the social responsible business for sustainable development in Vietnam. Besides that, the Women's Union, the Trade Union and the Ho Chi Minh Youth Union are included in the managerial form of SOEs and government agencies to protect the women right, workers and the youth. These organizations annually promote social activities and raise donation for disadvantaged people as part of their social responsibility projects in a way that they represent for the government. 
Through that CSR activities, the government promote and propaganda their political ideology (Abuza, 2001).

\section{State ownership, legislation and standards}

Despite of information about the degradation of state ownership, the party-state still keeping a major of share in enterprise community and have right to assign key leaders to key industrial sectors (Alpert, 2005). So that the government would have enough power to following the mission toward a social equality from socialism ideology, SOEs are trying to implement CSR practices, especially in erasing hunger and reducing poverty. In fact, there are information that many SOEs are providing facilities, healthcare and education systems in remote areas (Nguyen \& Crase, 2011). Besides, the gorvernment are also trying to adopt environmental protection regulations (Ortmann, 2017), legislation to protect the workers from inequal working-environment and the poor (Rodan et al., 2001). In case of pressure situations, the party-state can also apply their policymaking advantages due to legislation and state policies. Overall, the party-state wants to implement CSR activities by their proactive supervisor by keep themselves the owner of enterprises.

\subsection{Modernity}

Since 2000, Vietnam has had a significant transformation with the Doi Moi (Renovation) policy, which has led to the integration with foreign economies (Vuong, 2014). During this period, the government has adopted legislation in investment and trade to encourage private firms and foreign direct investments (FDIs) such as the establishment of the first stock market in 2000 and a series of bilateral trade agreements (Rowley \& Truong, 2009). In addition, Vietnam has jointed 13 FTAs (Free Trade Agreements) and 3 FTAs in negotiation (WTOcenter.vn). Besides, some of FTAs, for example, the EU Vietnam Free Trade Agreement (EVFTA) includes an article on Trade and Sustainable Development, listing obligations about labor and environmental issues for both Vietnam and Europe. Or, in the U.S.-Vietnam textiles agreement included an regulation that the Vietnamese authorities need to encourage exporting enterprises to implement CSR codes to approach the U.S. market. Hence, Vietnam need to follow these kinds of obligations as requirements from foreign partners to take advantage of FTAs such as import and export duties in global and regional context of comprehensive integration into the world.

Consequently, new industrial standards need to be established in business operation (Newman et al., 2018). It considered that business responsibilities with social need to be changed and Vietnamese enterprises have to manage their effect to social in a newer way (Anner, 2012; Tran \& Jeppesen, 2016). Thus, the government needs to modify, especially their legislation to implement global CSR practices to build reputation and image of country on business activities in global context (Newman et al., 2018).

Besides, the open-door policy of Vietnam to the world help Vietnamese have a chance to approach to wide source of socially responsible practices and ideas that can 
encourage CSR in domestic sector. Additionally, thank to international integration, Vietnamese can approach global technology, foreign educational system and new perspectives about global issues such as gender inequality, slavery, climate change, work-life balance (Edwards \& Phan, 2014). All of these things would drive the CSR practices in Vietnam.

\section{PROBLEMS AND MANAGERIAL RECOMMENDATIONS}

\section{The party-state legislation, policies and standards}

It has a concern that the legislation and policies are still incomplete and monopoly to apply effectively or not proper to the particular situation of Vietnam. Besides, the weak legal enforcement and issues is considerable and the lack of supervision of government to the lower bureaucratic local systems is critical too (Gillespie \& Nicholson, 2005). In addition, corruption and group interest are two of the most problem of Vietnam society, among 175 countries, Vietnam ranked $119^{\text {th }}$ place in corruption perception index 2014 by Transparency International. Corruption happening in government and business community is the daily issues that enterprises must face.

Besides, some of CSR factors in Vietnam such as salary, compensations, other working-related are different from international partners and very complicated. For example, there are many differences between Vietnam Labor Code and International partners Code of Conducts.

In conclusion, the party-state need to facilitate effectively CSR implementation by a complete and sufficient national legal frame that enterprises can't utilize in order to avoid their social responsibilities. Besides, they need to upgrade their current legal in concern of business ethnic and working environment to easily apply new CSR practices from developed countries. The concept of CSR needs to be included in university level by government. The party-state would promote CSR initiatives among businesses and inspect and organize government agencies to avoid the bureaucracy.

\section{Modernity - Enterprises perception}

According to the 2017 Economy Census released by the General Statistics Office of Vietnam (GSO), $98 \%$ of the firms in Vietnam is small and medium enterprise (SMEs). The implementation of CSR in SMEs are facing many problems which are the lack of finance and human resources, size of business, most of the cases the CEO is also business owner. They tend to maximize their profits than doing CSR.

Besides, there is the lack of commitment for CSR, they pursue the short-term incentive more than long-term and sustainable development. Even some companies implementing effective CSR practices with leaning toward more sustainable development still face trouble because Vietnam lack CSR trained professionals and CSR has never been taught in any university and college. 
Businesses need to raise the awareness of all level employees, change their attitude from "CSR as a cost" to "CSR as an investment" an then "CSR as a competitive advantage". They need to lean toward the more long-term and sustainable development and taking CSR as a serious thing that need time and dedication to deal with. Human resource would play an important role in CSR implementation strategies. In the context of integration, the enterprises need to have initiatives and renovation to reform and adapt with the foreign competitive competitors to find a more effective way to doing business profitably in term of CSR compliance.

\section{Tradition and Modernity - Low CSR awareness of Consumers or community}

According to a CSR Survey conducted by SRI Vietnam, 90\% of interviewees misunderstand the idea of CSR. Vietnam consumer perception about CSR is still vague, even they have been through the consequences from operation activities of corporations. $40 \%$ of interviewees consider CSR practices just as community works events and PR (Public relations) activities.

Community need to be more responsible and smarter when choosing a brand to buy goods because if they support wrong companies who have the low awareness about CSR, they will be the one suffer from consequences. And through that, they can affect to make companies more and more considering about CSR.

\section{CONCLUSION}

In term of CSR, in contextual perception, three factors that can promote CSR in Vietnam are tradition, the party-state and the modernity. Two main key players in this concept are government and enterprises who can affect mainly the implementation of CSR in Vietnam. In two factors, they have an interrelationship and interact to each other. Each one can't success in CSR practices without the collaboration of other.

Finally, Corporate Social Responsibility in detail or Social Responsibility in general are not only the matter of business community but also the matter of all society.

\section{BIBLIOGRAPHY}

Abuza, Z. (2001). Renovating politics in contemporary Vietnam. London: Lynne Rienner Publishers, Inc.

Alpert, W. T. (2005). The Vietnamese economy and its transformation to an open market system. Armonk, N.Y.: M.E. Sharpe.

Anner, M. (2012). Corporate social responsibility and freedom of association rights: The precarious quest for legitimacy and control in global supply chains. Politics and Society, 40(4), 609-644. https://doi.org/10.1177/ 0032329212460983. 
Bilowol, J., \& Doan, M. A. (2015). Multinational corporations' role in developing Vietnam's public relations industry through corporate social responsibility. Public Relat Rev, 41(5), 825-832. https://doi.org/10.1016/j.pubrev.2015.06.004.

Chính, P. M., \& Hoàng, V. Q. (2009). Kinh tế Việt Nam: Thăng trầm và đột phá. Nxb Chính trị quốc gia, Hà Nội.

Edwards, V., \& Phan, A. (2008). Vietnam. In J. Benson \& Y. Zhu (Eds.), Trade unions in asia: An economic and sociological analysis. London: Routledge.

Edwards, V., \& Phan, A. (2014). Managers and management in Vietnam: 25 years of economic renovation (Doi moi). Oxford: Routledge.

Gillespie, J., \& Nicholson, P. (Eds.). (2005). Asian socialism and legal change: The dynamics of Vietnamese and Chinese reform. Canberra: ANU Press and Asia Pacific Press.

Greenhouse, S. (1997). Nike shoe plant in Vietnam is called unsafe for workers. The New York Times.

Retrieved from http://www.nytimes.com/1997/11/08/business/nike-shoe-plant-invietnam-is-called-unsafe-for-workers.html

Hamm, B. (2012). Corporate social responsibility in Vietnam: Integration or mere adaptation? [press release].

lyer, B. (2013, May 28). Why consumers in Vietnam are calling for a ban on Coke. Campaign Asia-Pacific Magazine (e-magazine). Retrieved from:

http://www.campaignasia.com/article/why-consumers-in-vietnam-are-calling-for-a-banon-coke/344805

Newman, C., Rand, J., Tarp, F., \& Trifkovic, N. (2018). The transmission of socially responsible behaviour through international trade. Eur Econ Rev, 101, 250-267. https://doi.org/10.1016/j.euroecorev.2017.10.013.

Nguyen, P., \& Crase, L. (2011). Vietnam's state-owned enterprise reform: An empirical assessment in the international multimodal transport sector from the Williamson's TCE perspective. Asia Pacific Journal of Marketing and Logistics, 23(3), 411-422. doi:10.1108/13555851111143286

Nguyen, S., J. (2018). Corporate social responsibility (CSR) in Vietnam: a conceptual framework. International Journal of Corporate Social Responsibility

Ortmann, S. (2017). Environmental governance in Vietnam: Institutional reforms and failures. Cham: Palgrave Macmillan.

Rowley, C., \& Truong, Q. (2009). The changing face of Vietnamese management. Oxford: Routledge. 
Rodan, G., Hewison, K., \& Robison, R. (Eds.). (2001). The political economy of SouthEast Asia: Conflicts, crises, and change (2nd ed.). New York: Oxford University Press.

Tran, A. N. (2011). Corporate social responsibility in socialist Vietnam: Implementation, challenges, and local solutions. In A. Chan (Ed.), Labour in Vietnam (pp. 119-159). Singapore: Institute of Southeast Asian Studies.

Tran, A. N., \& Jeppesen, S. (2016). SMEs in their own right: The views of managers and workers in Vietnamese textiles, garment, and footwear companies. J Bus Ethics, 137(3), 589-608. https://doi.org/10.1007/s10551-015-2572-x.

Tran, A. N., \& Jeppesen, S. (2016). SMEs in their Own Right: The Views of Managers and Workers in Vietnamese Textiles, Garment, and Footwear Companies. Journal of Business Ethics, 137(3), 589-608. doi:10.1007/s10551-015-2572-x

Tuoi Tre News. (2017). Ex-director of Vietnamese pharmaceutical firm stands trial for importing fake medicine. Tuoi Tre News.

Retrieved from http://tuoitrenews.vn/news/society/20170821/exdirector-of-vietnamesepharmaceutical-firm-stands-trial-for-importing-fake-medicine/41060.html

Visser, W., Andrew, C., Dirk, M., Abagail, M., Jeremy, M., \& Donald, S. S. (2008). Corporate social responsibility in developing countries: 'Oxford University Press'.

Vuong, Q. (2014). Vietnam's political economy in transition (1986-2016). Stratfor Wordview. Retrieved from https://worldview.stratfor.com/the-hub/vietnamspoliticaleconomy-transition-1986-2016 